ACTA MYCOLOGICA

Vol. 41 (1): 41-48

2006
Dedicated to Professor Alina Skirgietto

on the occasion of her ninety fifth birthday

\title{
Acaulospora rehmii and Gigaspora margarita, arbuscular mycorrhizal fungi (Glomeromycota) new for Europe and Poland, respectively
}

\author{
JANUSZ BŁASZKOWSKI, SŁAWOMIR KOWALCZYK and BEATA CZERNIAWSKA
}

Department of Plant Pathology, University of Agriculture

Słowackiego 17, PL 71434 Szczecin, jblaszkowski@agro.ar.szczecin.pl

Błaszkowski J., Kowalczyk S., Czerniawska B.: Acaulospora rehmii and Gigaspora margarita, arbuscular mycorrhizal fungi (Glomeromycota) new for Europe and Poland, respectively. Acta Mycol. 41 (1): 41 48, 2006.

Morphological characters of spores of Acaulospora rehmii and Gigaspora margarita (Glomeromycota) were described and illustrated. Spores of the two species were found in field collected mixtures of rhizosphere soil and roots collected in Poland. Attempts to produce spores in trap cultures succeeded only with $G$. margarita. All attempts to establish one species cultures of the two fungi failed. Gigaspora margarita was for the first time found in Poland and this paper is the first report of the occurrence of $A$. rehmii in Europe. The known distribution of the two fungal species in the world is also presented.

Key words: arbuscular fungi, Glomeromycota, mycorrhizae, distribution

\section{INTRODUCTION}

Continuing over 20-year studies of the occurrence of arbuscular mycorrhizal fungi of the phylum Glomeromycota, spores of Acaulospora rehmii Sieverd. et S. Toro and Gigaspora margarita W.N. Becker et I.R. Hall, species earlier not recorded in Europe and Poland, respectively, were found.

The aims of this paper are to describe and illustrate morphological characters of spores of $A$. rehmii and $G$. margarita and to present the distribution of these fungi in Poland and the other regions of the world.

\section{MATERIALS AND METHODS}

Establishment of trap cultures and one-species cultures. Rhizosphere soils and roots of sampled plants were collected from a depth of 5-30 cm using a small garden shovel. In the laboratory, about 100 -g subsamples were taken from each sample to isolate spores of arbuscular mycorrhizal fungal species sporulating in the field. The remaining part of the sample was either air dried for 2 weeks and subsequently refrigerated at $4^{\circ} \mathrm{C}$ or directly used to establish trap cultures. Trap cultures were estab- 
lished to obtain a great number of living spores and to initiate sporulation of species that were present but not sporulating in the field collections. The growing substrate of the trap cultures was the field-collected material mixed with an autoclaved coarsegrained sand coming from maritime dunes adjacent to Świnoujście (pH 6.7; 12 and $26 \mathrm{mg} \mathrm{L}^{-1} \mathrm{P}$ and $\mathrm{K}$, respectively; Błaszkowski 1995). The mixtures were placed in $9 \times 12.5-\mathrm{cm}$ plastic pots $\left(500 \mathrm{~cm}^{3}\right)$ and densely seeded with Plantago lanceolata $\mathrm{L}$. Plants were grown in a greenhouse at $15-30^{\circ} \mathrm{C}$ with supplemental 8-16-h lighting provided by one SON-T AGRO sodium lamp (Philips Lighting Poland S. A.) placed $1 \mathrm{~m}$ above pots. The maximum light intensity was $180 \mu \mathrm{E} \mathrm{m}^{-2} \mathrm{~s}^{-1}$ at pot level. Plants were watered 2-3 times a week. No fertilizer was applied during the growing period. Trap cultures were harvested five to seven months after plant emergence. Spores were extracted by wet sieving and decanting (Gerde man n, Nicols on 1963). Presence of mycorrhizae was determined following clearing and staining of roots (Phillips, Hayman 1970) modified as follows: tissue acidification with $20 \% \mathrm{HCl}$ instead of $1 \%$, and trypan blue concentration $0.1 \%$ instead of $0.05 \%$ (Ko s ke, pers. comm.).

Single-species pot cultures were established from about 10-20 spores stored before inoculation in water at $4^{\circ} \mathrm{C}$ for $24 \mathrm{~h}$. After removal of soils debris, spores were collected in a pipette and transferred onto a compact layer of mycorrhizae-free roots of 10-14 day old seedlings of $P$. lanceolata placed at the bottom of a hole $c a .1 \mathrm{~cm}$ wide and $4 \mathrm{~cm}$ deep formed in a wetted growing medium filling $8-\mathrm{cm}$ plastic pots $\left(250 \mathrm{~cm}^{3}\right)$. The growing medium was an autoclaved sand of maritime dunes adjacent to Świnoujście with chemical properties listed above. Subsequently, the spores were covered with another layer of roots of 4-6 additional $P$. lanceolata seedlings, and the roots and sandwiched spores were buried in the growing medium. Finally, three to six seeds of $P$. lanceolata were placed on the surface of the growing substrate and covered with a thin layer of autoclaved sand. The cultures were harvested after 4-8 months.

Microscopy survey. Morphological properties of spores and their subcellular structures were determined based on at least 20 spores mounted in polyvinyl alcohol/lactic acid/glycerol (PVLG; Omar, Bollan, Heather 1979) and a mixture of PVLG and Melzer's reagent (1:1, v/v). Spores were crushed to varying degrees by applying pressure to the coverslip and then stored at $65^{\circ} \mathrm{C}$ for $24 \mathrm{~h}$ to clear their contents of oil droplets. These were examined under an Olympus BX 50 compound microscope equipped with Nomarski differential interference contrast optics. Microphotographs were recorded on a Sony 3CDD colour video camera coupled to the microscope.

Terminology of spore structure is that suggested by Stürmer \& Morton (1997) and Walker $(1983,1986)$. Spore colour was examined under a dissecting microscope on fresh specimens immersed in water. Colour names are from Kornerup \& Wanscher (1983). Nomenclature of fungi and plants is that of Walker \& Trappe (1993) and Mirek et al. (1995), respectively. The authors of the fungal names are as those presented at the URL web page http://www.indexfungorum. org/AuthorsOfFungalNames.htm. Specimens were mounted in PVLG on slides and deposited in the Department of Plant Pathology (DPP).

Colour microphotographs of spores and mycorrhizae of A. rehmii and G. margarita can be viewed at the URL http://www.agro.ar.szczecin.pl/ jblaszkowski/. 


\section{DESCRIPTIONS OF THE SPECIES}

\section{Acaulospora rehmii Sieverd. et S. Toro}

Spores single in the soil; develop laterally on the neck of a sporiferous saccule. Spores dull yellow (3B3) to Nankeen yellow (3B7); globose to subglobose; (90-)140(-165) $\mu \mathrm{m}$ diam. Subcellular structure of spores consists of a spore wall and two inner germination walls (Fig. 1). Spore wall composed of three layers (layers 1-3). Layer 1 evanescent, hyaline, (0.8-)1.0(-1.2) $\mu \mathrm{m}$ thick (Fig. 2), continuous with the wall of a sporiferous saccule, rarely present in mature spores. Layer 2 laminate, dull yellow (3B3) to Nankeen yellow (3B7), (4.5-)10.0(-12.0) $\mu \mathrm{m}$ thick, ornamented with labyrinthine folds, $1.0-3.5 \mu \mathrm{m}$ wide and $1.0-4.5 \mu \mathrm{m}$ high when seen in a plane view and a cross view, respectively (Figs 1-3). Layer 3 semi-flexible, hyaline, (0.5-)0.7(-0.8) $\mu \mathrm{m}$ thick, rarely separable from layer 2 (Fig. 2). Germination wall 1 consists of two tightly adherent hyaline, semi-flexible layers, each $0.5-0.8 \mu \mathrm{m}$ thick; these layers are tightly adherent to each other and, hence, difficult to see (Figs 1, 2, $4,5)$. Germination wall 2 composed of two adherent layers (layers 1 and 2; Figs 1 and 2). Layer 1 flexible, hyaline, (0.5-)0.7(-1.0) $\mu \mathrm{m}$ thick, covered with small, $<0.5 \mu \mathrm{m}$ diam, granules scattering in crushed spores (Figs 4 and 5). Layer 2 flexible, hyaline, (0.6-)1.1(-1.4) $\mu \mathrm{m}$ thick in PVLG; its staining reaction in Melzer's reagent was not examined. Germination orb not observed. Sporiferous saccule hyaline; globose to subglobose; $90-150 \mu \mathrm{m}$ diam, with a 1-layered wall, $0.8-1.7 \mu \mathrm{m}$ thick; neck 50-80 $\mu \mathrm{m}$ long, tapering from 15.0-22.0 $\mu \mathrm{m}$ wide at the saccule to $12.0-19.0 \mu \mathrm{m}$ wide at the spore attachment. Saccule usually collapses and is detached in mature spores. Cicatrix remaining after sporiferous saccule detachment is a slightly raised, circular scar, 8.0-11.5 $\mu \mathrm{m}$ diam (Fig. 6).

The unique character of spores of $A$. rehmii is the labyrinthine ornamentation of their structural laminate layer. The properties of the other layers of both the spore wall and the inner germination walls are similar to those of most the other species of the genus Acaulospora.

Acaulospora rehmii is one of the nine recognized species of the genus Acaulospo$r a$ producing spores with an ornamented laminate structural layer. When observed under a dissecting microscope, spores of $A$. rehmii are dull because of the ornamented structural laminate layer and, thereby, most resemble in size and colour spores of $A$. bireticulata F.M. Rothwell et Trappe, $A$. dendiculata Sieverd. et S. Toro, A. lacunosa J.B. Morton, $A$. spinosa C. Walker et Trappe, and $A$. tuberculata Janos et Trappe, fungi also producing ornamented spores. However, examination of crushed spores of $A$. rehmii under a compound microscope reveals them to be ornamented with labyrinthine processes (Fig. 3), and those of $A$. bireticulata with polygonal reticulum with isolated projections at polygon centres (Błaszkowski 2003; Morton 2002; Rothwell, Trappe 1979), A. denticulata with stubby knobs (Morton 2002; Sieverding, Toro 1987), A. lacunosa with round, prolate or irregularly-shaped pits (Błaszkowski 2003; Morton 1986, 2002), A. spinosa with closely packed rounded spines (Walker, Trappe 1981), and $A$. tuberculata with polygonal spines or tubercles (Janos, Trappe 1982; Morton 2002).

Other species of Acaulospora forming spores with an ornamented outer surface of their laminate structural layer are $A$. foveata Trappe and Janos, $A$. paulinae Błaszk., A. scrobiculata Trappe, and $A$. undulata Sieverd. Compared with spores of 
A. rehmii, those of $A$. foveata are much greater [(240-)289(-300) vs. (82-)141(-175) $\mu \mathrm{m}$ diam in $A$. rehmii] and darker-coloured (red-orange to dark red-brown vs. light yellow to orange-brown), and spores of $A$. paulinae, $A$. scrobiculata, and $A$. undulata are lighter (hyaline to straw-coloured; Błaszkowski 2003; Morton 2002; Sieverding, Toro 1987). Additionally, spores of the latter two species are much smaller (55-92 um diam; Błaszkowski 2003; Si everding 1988). Finally, spores of all the species compared here are ornamented with pits, and not with labyrinthine processes as those of $A$. rehmii.

Another important difference between $A$. rehmii and $A$. bireticulata, A. foveata, and $A$. tuberculata resides in the inner layer of the second germination wall of their spores. While this layer is thin and flexible in $A$. rehmii (Figs. 4 and 5), that of $A$. bireticulata, $A$. foveata, and $A$. tuberculata is much thicker and corresponds with the coriaceous wall sensu Walker (1986).

Collections examined. Poland. All from Władysławowo (54눅' $\left.\mathrm{N}, 18^{\circ} 26^{\prime} \mathrm{E}\right)$, in the root zone of Melilotus officinalis (L.) Pall., 20 Sept. 1996, Błaszkowski J. 2656-2660 (DPP); under P. lanceolata, 20 Sept. 1996, Błaszkowski J. 2661-2663 (DPP); from among roots of Trifolium repens L., 20 Sept. 1996, Błaszkowski J. 2664-2669 (DPP).

Distribution and habitat. In Poland, spores of $A$. rehmii were found in three field-collected samples of roots and rhizosphere soils taken under $M$. officinalis, $P$. lanceolata, and T. repens. All the plant species grew in a salt pan near Władysławowo at the beginning of the Hel Peninsula.

Acaulospora rehmii has originally been isolated from a crop field at Caicedonia, Valle de Cauca, Colombia (Sieverding, Toro 1987). This fungus has been associated with Manihot esculentum, Phaseolus, Sorghum and Crotalaria species. Additionally, Sieverding and Toro (1987) found spores of $A$. rehmii in a culture containing a soil sample coming from the Centro de Pesquisa Agropecuária dos Cerrados, Brasilia D. F., Brazil. Recently, Mor eir a-S ou za et al. (2003) confirmed the presence of this fungus in Brazil; $A$. rehmii spores were encountered among roots of Araucaria angustifolia (Bert.) O. Ktze growing in a reforested area in the State Park of Campos do Jordão, San Paulo. Wu \& Liu (1995) isolated spores of A. rehmii from among roots of Phyllostachys pubescens Mazel growing in a garden in Chi-tou Experimental Station, National Taiwan University. Thus, this paper for the first time informs of the occurrence of $A$. rehmii in Europe.

Mycorrhizal associations. In Poland, $A$. rehmii has been associated with vesicular-arbuscular mycorrhizal roots of $P$. lanceolata. Many attempts to initiate sporulation of this fungus in both trap and one-species cultures failed. According to S i e ve r ding \& Toro (1987), A. rehmii produced vesicular-arbuscular mycorrhizae.

\section{Gigaspora margarita W.N. Becker et I.R. Hall}

Spores produced singly in the soil, blastically at the tip of a bulbous sporogenous cell (Fig. 7). Spores yellowish white (4A2) to sunflower yellow (4A7); globose to sub-


Subcellular structure of spores consists of a spore wall comprising two layers (layers 1-3; Figs 8 and 9) and a one-layered germination wall. Spore wall layer 1, forming the spore surface, permanent, smooth, hyaline, (1.7-)1.9(-2.2) $\mu \mathrm{m}$ thick (Figs. 8 and 9), sometimes separating from layer 2 in crushed spores. Layer 2 of spore wall laminate, smooth, yellowish white (4A2) to sunflower yellow (4A7), (19.4-)23.4(-26.2) $\mu \mathrm{m}$ 
thick, consisting of a variable number of laminae, each (1.2-)1.5(-1.7) $\mu \mathrm{m}$ thick, usually separating from each other in crushed spores (Figs 8 and 9). Germination wall permanent, flexible to semi-flexible, concolorous with spore wall layer 2, (1.5-)1.6(-1.8) $\mu \mathrm{m}$ thick (Figs 8 and 9), covered with processes on its under surface (Fig. 10); processes 3.7-7.6 x 2.6-3.9 $\mu \mathrm{m}$, spaced 1.7-13.5 $\mu \mathrm{m}$ from each other; forming prior to germination. In Melzer's reagent, only spore wall layer 2 stains deep red (11C8; Fig. 11). Sporogenous cell orange (5B8) to brownish yellow (5C8), clavate; 52.5-60.0 x 75.0-100.0 $\mu \mathrm{m}$ (Figs 7, 11, 12). Wall of sporogenous cell composed of two layers (Figs 11 and 12). Layer 1 hyaline, (1.0-)1.7(-2.0) $\mu \mathrm{m}$ thick, continuous with spore wall layer 1 (Fig. 11). Layer 2 orange (5B8) to brownish yellow (5C8), (4.7-)5.6(-6.4) $\mu \mathrm{m}$ thick, continuous with spore wall layer 2 (Fig. 11).

Of the eight described species of the genus Gigaspora, Bentivenga \& Morton (1995) accepted five. Gigaspora candida Bhattacharjee et al., G. ramisporophora Spain, Sieverd. and N.C. Schenck, and G. tuberculata Neeraj et al. were considered congeneric with G. rosea Nicol. et N.C. Schenck, G. margarita, and Scutellospora persica (Koske et C. Walker) C. Walker et F.E. Sanders, respectively.

The most distinctive characters of $G$. margarita are its yellow-coloured spores (Fig. 7), whose colour results from the pigmentation of the spore wall [is not associated with spore contents as in G. gigantea (Nicol. et Gerd.) Gerd. et Trappe], and their relatively thin, usually less than $25 \mu \mathrm{m}$ thick, wall.

The only other species of Gigaspora forming spores similar in size and colour to those of $G$. margarita is $G$. decipiens I.R. Hall et L.K. Abbott. The character separating the two fungi is the much thicker [(15-)20-45(-90) $\mu$ m; Bentivenga, Morton (1995)] spore wall of the former species.

All attempts to establish one-species cultures of $G$. margarita made by the authors of this paper failed. Hence, the ontogenetic development and the differentiation of subcellular structures of spores of this fungus were not recognized. According to Bentivenga \& Morton (1995), spores of G. margarita originate blastically from the top of a bulbous sporogenous cell and their wall consists of two, thin layers of near-equal thickness. At first, the spores are white. With time, the inner spore wall layer thickens and the spores darken because of the synthetization of new sublayers from the spore contents. The ontogenetic development of spores ends the formation of a germination wall ornamented with processes prior to germination. The germ tube penetrates through the spore wall.

Bentivenga \& Morton (1995) suggested that the two wall layers of spores of G. margarita and all the other Gigaspora spp. originating at the same time indicate them to be interdependent elements of one spore wall. A similar spore wall structure occurs in juvenile spores of members of the genus Scutellospora. This suggests that Gigaspora is ancestral to Scutellospora, the only other member of the family Gigasporaceae, although molecular analyses of ribosomal DNA did not confirm it (Simon et al. 1993).

Compared with fungi of all the other genera of the phylum Glomeromycota, species of Gigaspora distinguish the lowest morphological variability of their spores. Spores of all Gigaspora spp. are smooth and the characters separating them are only colour and size of spores, as well as thickness of their wall. Except for G. gigantea, whose colour of spores results from the pigmentation of their contents, the spore colour of the other species comes from their wall. Bentivenga \& Morton (1995) 
hypothesized that such low amount of diversity in Gigaspora results from two reasons. Firstly, germination of Gigaspora spp. is associated with spore wall and the energy remained after completion of this vital process probably is too low to aid further differentiation of this wall. In Scutellospora spp., germination is taken over by the germination shield, which enables the spore wall to unconstrainedly express variation. Secondly, the low level of variability in Gigaspora spp. may result from their recent separation and the lack of time to further diverge morphologically.

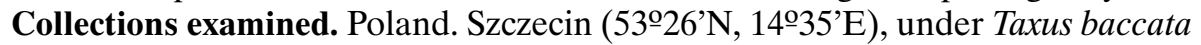
L., 2 May 2001, Błaszkowski J. 2670-2672 (DPP); Dąbrówka Wielkopolska (1549’E, 52 $\left.17^{\prime} \mathrm{N}\right)$, from under Rumex acetosella L., 22 July 2003, Błaszkowski J. 2673 (DPP);

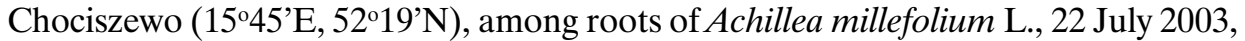

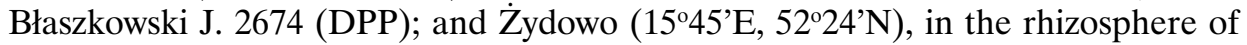
Polygonum persicaria L., 3 Aug. 2003, Błaszkowski J. 2675 (DPP).

Distribution and habitat. In Poland, G. margarita was found in four mixtures of roots and rhizosphere soils, of which three were collected in the Lubuskie province and one in the Western Pomerania province. All the mixtures represented wild plants. Of them, only $A$. millefolium and $P$. persicaria hosted spores of $G$. margarita in the field. However, the associations of $G$. margarita with roots of $P$. persicaria and T. baccata were revealed only after the cultivation of their field-collected roots and rhizosphere soils in trap cultures. The sporulation of $G$. margarita in both the field and trap cultures was low. Among the 109 spores of arbuscular fungi isolated from $100 \mathrm{~g}$ of dry field soil taken under $A$. millefolium, only one $(0.9 \%)$ belonged to $G$. margarita. Polygonum persicaria growing in the field hosted a total of 77 spores in 100 $\mathrm{g}$ of dry soil, including two $(2.6 \%)$ of $G$. margarita.

In trap cultures with $Z$. mays as the plant host and mixtures of roots and rhizosphere soils of $R$. acetosella and T. baccata, the densities of $G$. margarita spores were 2 and 9 in $100 \mathrm{~g}$ of dry soil, respectively, and G. margarita was the only arbuscular fungus revealed.

In the field, other species of arbuscular fungi associated with roots of $A$. millefolium were Glomus aggregatum N.C. Schenck et S.M. Sm. emend. Koske, Gl. constrictum Trappe and Scutellospora dipurpurescens J.B. Morton et Koske, and Gl. constrictum and Gl. deserticola Trappe, Bloss et J.A. Menge occurred among roots of $P$. persicaria.

Gigaspora margarita probably has a worldwide distribution. The holotype of this fungus has been selected from spores recovered from under Glycine max (L.) Merr. growing in a pot culture containing a root x rhizosphere soil mixture of $G$. max cultivated at the Agronomy South Farm of University of Illinois, USA (B e cke r, Hall 1976). Apart from many other reports of the occurrence of Gigaspora margarita in both cultivated (agricultural soils, orchards, nurseries) and natural sites (maritime sand dunes, native woodland, prairie) of the US (An et al. 1993; Hetrick, Bloom 1983; Koske, Gemma 1997; Menge et al. 1977; Miller, Domoto, Walker 1985; Nicolson, Schenck 1979; Rose 1988; Schenck, Kinloch 1980; Schenck, Smith 1981), this species has also been found associated with different cultivated and uncultivated plants of Japan (Saito, Vargas 1991), New Zealand (Hall 1977), China (Wu et al. 2002), Canada (Marcel et al. 1988; Ha mel et al. 1994), Mexico (Estrada-Torres et al. 1992), Cuba (Ferrer, Herrera 1980), and South America (Moreira-Souza et al. 2003; Sieverding 1989). 


\section{REFERENCES}

An Z. Q, Hendrix J. W., Hershamn D. E., Ferriss R. S., Henson G. T. 1993. The influence of crop rotation and soil fumigation on a mycorrhizal fungal community associated with soybean. Mycorrhiza 3: 171182.

Becker W. N., Hall I. R. 1976. Gigaspora margarita, a new species in the Endogonaceae. Mycotaxon 4: 155160 .

Bentiveng a S. P., Morton J. B. 1995. A monograph of the genus Gigaspora, incorporating develop mental patterns of morphological characters. Mycologia 87: 719731.

Błaszkowski J. 1995. Glomus corymbiforme, a new species in Glomales from Poland. Mycologia 87: 732737.

Błaszkowski J. 2003. Arbuscular mycorrhizal fungi (Glomeromycota), Endogone, and Complexipes species deposited in the Department of Plant Pathology, University of Agriculture in Szczecin, Po land. http://www.agro.ar.szczecin.pl/ jblaszkowski/.

Estrada Torres A., Varela L., Hernandez Cuevas L., Gavito M. E. 1992. Algunos hongos micorrizicos arbusculares del estado de Tlaxcala, México. Rev. Mex. Mic. 8: 85110.

Ferrer R. L., Herrera R. A. 1980. El genero Gigaspora Gerdemann et Trappe (Endogonaceae) en Cuba. Rev. Jar. Bot. Nac. Habana 1: 4366.

Ge r d e m a n J. W., Nicols on T. H. 1963. Spores of mycorrhizal Endogone species extracted from soil by wet sieving and decanting. Trans. Brit. Mycol. Soc. 46: 235244.

Hall I. R. 1977. Species and mycorrhizal infections of New Zealand Endogonaceae. Trans. Br. Mycol. Soc. 68: 341356.

Hamel C., Dalpe Y., Lapierre C., Simard R. R., Smith D. L. 1994. Composition of the vesicu lar arbuscular mycorrhizal fungi population in an old meadow as affected by $\mathrm{pH}$, phosphorous and soil disturbance. Agric. Ecosyst. Environ. 49: 223231.

Hetrick B. A. D., Bloom J. 1983. Vesicular arbuscular mycorrhizal fungi associated with native tall grass prairie and cultivated winter wheat. Can. J. Bot. 61: 21402146.

Jan o s D. P., Trappe J. M. 1982. Two new Acaulospora species from tropical America. Mycotaxon 15: 515522.

Kornerup A., Wanscher J. H. 1983. Methuen handbook of colour. 3rd Ed. E. Methuen and Co., Ltd., London. 252 pp.

Ko ske R. E., Ge m m a J. N. 1997. Mycorrhizae and succession in plantings of beachgrass in sand dunes. Am. J. Bot. 84: 118130.

Marcel G. A., van der Heiden M. G. A., Klironomos J. N., Ursic M., Moutoglis P., Strei twolf Engel R., Boller T., Wiemken A., S anders I. R. 1988. Mycorrhizal fungal diversity determines plant biodiversity, ecosystem variability and productivity. Nature 396: 6972 .

Menge J. A., N e me c S., D avis R. M., Min assian V. 1977. Mycorrhizal fungi associated with citrus and their possible interactions with pathogens. Proc. Int. Soc. Citriculture 3: 872876.

Mille r D. D., Dom ot o P., Walke r C. 1985. Mycorrhizal fungi at eighteen apple rootstock plantings in the United States. New Phytol. 100: 379391.

Mirek Z., Pięk koś Mirkowa H., Zają c A., Zają c M. 1995. Vascular plants of Poland. A Checklist. Polish Botanical Studies, Guidebook 15, Kraków. 303 pp.

Moreira Souza M., Truem S. F. B., Gomes da Costa S. M. Cardoso E. J. B. N. 2003. Ar buscular mycorrhizal fungi associated with Araucaria angustifolia (Bert.) O. Ktze. Mycorrhiza 13: 211215.

Mort on J. B. 1986. Three new species of Acaulospora (Endogonaceae) from high aluminum, low pH soils in West Virginia. Mycologia 78: 641648.

Morton J. B. 2002. International Culture Collection of Vesicular) Arbuscular Mycorrhizal Fungi. West Virginia University: http://www.invam.caf.wvu.edu/.

Nicolson T. H., Schenck N. C. 1979. Endogonaceous mycorrhizal endophytes in Florida. Mycologia 71: 178198.

O mar M. B., Bollan L., He at her W. A. 1979. A permanent mounting medium for fungi. Bull. Brit. Mycol. Soc. 13: 3132.

Phillip s J. M., Hay m an D. S. 1970. Improved procedures for clearing roots and staining parasitic and vesicular arbuscular mycorrhizal fungi for rapid assessment of infection Trans. Brit. Mycol. Soc. 55: 158161. 
Rose S. 1988. Above and belowground community development in a maritime sand dune ecosystem. Plant and Soil 109: 215226.

Rothwell F. M., Trappe J. M. 1979. Acaulospora bireticulata sp. nov. Mycotaxon 8: 471475.

Saito M., Vargas R. 1991. Vesicular arbuscular mycorrhizal fungi in some humus rich Ando soils of Japan. Soil Microorg. 38: 315.

Schenck N. C., Kinloch R. A. 1980. Incidence of mycorrhizal fungi on six field crops in monoculture on a newly cleared woodland site. Mycologia 72: 445456.

Schenck N. C., Smith G. S. 1981. Distribution and occurrence of vesicular arbuscular mycorrhizal fungi on Florida agricultural crops. Soil and Crop Sci. Soc. Florida 40: 171175.

Sieverding E. 1988. Two new species of vesicular arbuscular mycorrhizal fungi in the Endogonaceae from tropical high lands of Africa. Angew. Bot. 62: 373380.

Sieverding E. 1989. Ecology of VAM fungi in tropical ecosystems. Agric., Ecosyst. and Environ. 29: 369390.

Sieverding E., Toro S. T. 1987. Acaulospora dendiculata sp. nov. and Acaulospora rehmii sp. nov. (Endogonaceae) with ornamented spore walls. Angew. Bot. 61: 217223.

Simon L., B ousquet T., Léves que R. C., Lalonde M. 1993. Origin and diversification of endomy corrhizal fungi and coincidence with vascular land plants. Nature 363: 6769.

Stürmer S. L., Morton J. B. 1997. Developmental patterns defining morphological characters in spores of four species in Glomus. Mycologia 89: 7281.

Walker C. 1983. Taxonomic concepts in the Endogonaceae: Spore wall characteristics in species de scriptions. Mycotaxon 18: 443455.

Walker C. 1986. Taxonomic concepts in the Endogonaceae. II. A fifth morphological wall type in en dogonaceous spores. Mycotaxon 25: 9599.

Walke r C., Trappe J. M. 1981. Acaulospora spinosa sp. nov. with a key to the species of Acaulospora. Mycotaxon 12: 515521.

Walker C., Trappe J. M. 1993. Names and epithets in the Glomales and Endogonales. Mycol. Res. 97: 339344 .

Wu T., Ha o W., Lin X., Shi Y. 2002. Screening of arbuscular mycorrhizal fungi for the revegetation of eroded red soils in subtropical China. Plant and Soil 239: 225235.

Wu C. G., Li u Y. S., Hwu ang Y. L., Wang Y. P., Ch a o C. C. 1995. Glomales of Taiwan: V. Glomus chimonobambusae and Entrophospora kentinensis, spp. nov. Mycotaxon 53: 283294.

\section{Acaulospora rehmii i Gigaspora margarita, arbuskularne grzyby mikoryzowe (Glomeromycota) nowe odpowiednio dla Europy i Polski}

\section{Streszczenie}

Opisano i zilustrowano cechy morfologiczne zarodników Acaulospora rehmii i Gigaspora margarita, arbuskularnych grzybów mikoryzowych z gromady Glomeromycota. Zarodniki obu tych gatunków znaleziono w polowych mieszaninach gleby ryzosferowej i korzeni zebranych w Polsce. Próby otrzymania zarodników tych grzybów w kulturach pułapkowych powiodły się tylko z G. margarita. Wszystkie próby ustanowienia jednogatunkowych kultur obu grzybów nie udały się. Gigaspora margarita znaleziono po raz pierwszy w Polsce, a A. rehmii po raz pierw szy w Europie. Przedstawiono również poznane rozmieszczenie obu gatunków w świecie. 